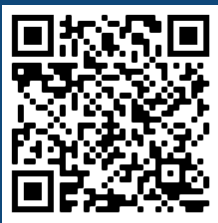

Keywords:

Conservation

Clonal forestry

Adventitious rooting

Forest nutrition

Geographical origin

Historic: Received 20/05/2020 Accepted 10/09/2020

Correspondence:

Aline Ramalho dos Santos ${ }^{1 a+}$, Elzimar de Oliveira Gonçalves ${ }^{1 b}$, Elbya Leão Gibson ${ }^{l c}$, Emanuel França Araújo ${ }^{\text {Id, }}$ Ivar Wendling ${ }^{2 a}$, Lara Arêas Tertuliano'e, Marcos Vinicius Winckler Caldeira ${ }^{\text {If }}$

\title{
MINI-CUTTINGS TECHNIQUE FOR VEGETATIVE PROPAGATION OF Dalbergia nigra
}

SANTOS, A. R. dos; GONÇALVES, E. de O.; GIBSON, E. L.; ARAÚJO, E. F.; WENDLING, I. ; TERTULIANO, L. A.; CALDEIRA, M. V. W. Mini-cuttings technique for vegetative propagation of Dalbergia nigra. CERNE, v. 26, n. 4, p.427-434, 2020.

\section{HIGHLIGHTS}

The genotype affects the quality of the mini-cuttings root system.

Stock plant nutrition was positively related to adventitious rooting.

Indole-3-butyric acid was not conditioning for adventitious rooting mini-cuttings.

The protocol enables mass propagation and vegetative recues of $D$. nigra genotypes.

\section{ABSTRACT}

The usual propagation method for Dalbergia nigra is via seedings; however, the seasonal supply has a variable quantity of seeds which limits the continuous production of seedlings. Therefore, the objective of this study was to establish a vegetative propagation protocol via mini-cuttings technique for $D$. nigra from juvenile shoots obtained from seedlings. The experimental design was completely randomized in a $2 \times 2 \times 4$ factorial scheme, with two geographical origins: two controlled release fertilizer doses $\left(4.0\right.$ and $\left.8.0 \mathrm{~g} \cdot \mathrm{dm}^{-3}\right)$ and four indole-3-butyric acid (IBA) concentrations (0; 2,000; 4,000; and 6,000 $\mathrm{mg}^{-\mathrm{Kg}^{-1}}$ ), with four replications. The mini-cuttings were removed from the tubes after 60 days of propagation in the greenhouse, and the substrate was completely removed by washing in running water to observe the roots. The survival percentage, rooting, rooting speed and variables

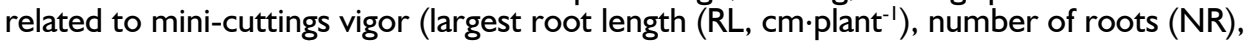
surface area $\left(\mathrm{SA}, \mathrm{mm}^{2}\right)$, root volume $\left(\mathrm{RV}, \mathrm{mm}^{3}\right)$ and root dry mass (RDM, g.plant $\left.{ }^{-1}\right)$ were measured. The results indicated that $D$. nigra has an aptitude for vegetative propagation by mini-cuttings with survival values and rooting greater than $70 \%$. Geographical origins present a different set of responses for survival, rooting and vigor of mini-cuttings. Stock plant nutrition influences mini-cuttings root growth. IBA concentrations did not promote an effect on the mini-cuttings rooting percentage; however, exogenous auxin at the dose of $6,000 \mathrm{mg} \cdot \mathrm{Kg}^{-1}$ provided mini-cuttings with greater vigor in their radical system. Nonetheless, further research is suggested to define the feasibility of using this regulator in the vegetative propagation of this species.

'Federal University of Espirito Santo, Jerônimo Monteiro, Espirito Santo, Brazil. ORCID: 0000-0002-1560-3555a', 0000-000 I-7675-2493b, 0000-0003-1924-I85 Ic, 0000-000 I-9090-6006 , 0000-0003-35I3-9363e, 0000-0003$469|-989|^{f}$ 


\section{INTRODUCTION}

Dalbergia nigra (Vell.) Fr. All. ex Benth., internationally known as Brazilian Rosewood, is an arboreal Fabaceae and is endemic to the Brazilian Atlantic Forest (Carvalho, 2003; Lima, 20I5). Its wood has natural beauty, quality and excellent technological properties, being considered one of the most valuable wood species occurring in Brazil and has been exported since colonial times (Carvalho, 2003). In detriment to these characteristics, it is known worldwide in the construction of luxury furniture, internal finishes in civil construction, furniture covering and musical instruments (Lorenzi, 2009).

D. nigra is currently listed as an endangered species due to the intense exploitation and degradation of its natural environment, and its national and international trade is prohibited, leaving few forest fragments with individuals of this species, and which are generally small and isolated (Brasil, 20I4). D. nigra propagation is commonly carried out by sowing seeds, however, the difficulty in obtaining viable seeds, plus the supra-annual flowering and fruiting with years of intense production followed by years of low production limit the commercial production of its seedlings (Carvalho, 2003). Its vegetative propagation has been difficult (Dias et al., 2012; Abiyu et al., 2016; Azad et al., 2018). In this sense, the vegetative propagation method offers the opportunity to produce a reliable and adequate supply of plants in a timely manner (Baul et al., 2010), becoming a key factor in the multiplication of the species (Jannat et al., 2017). Furthermore, it may be a key technique for multiplying superior plants of the species in the future in order to form clonal plantations with high productivity and uniformity.

The mini-cuttings technique has been used successfully in the forestry sector to maximize clonal production in Eucalyptus (Correia et al., 2015; Freitas et al.; 2017, Fernandes et al., 2018), Cariniana estrellensis (Gatti et al., 20II), Anadenanthera macrocarpa (Dias et al., 20I5), llex paraguariensis (Wendling et al., 2013) and Handroanthus heptaphyllus (Oliveira et al., 2016) species. However, adventitious rooting is a highly complex process and differs considerably between tree species, being influenced by the type of growth regulator, the concentration (Azad and Martin, 20I5; Azad et al., 2016), genotype, as well as the physiological and nutritional conditions of the donor stock plant (Hartmann et al., 20II; Xavier et al., 20I3; Wendling et al., 20I4).

A mini-clonal hedge is the basis of clonal propagation and its management, and generally the foundation of effective mass propagation (Xavier et al., 20/3). The supply of nutrients in ideal quantities while handling/managing the mini-stumps determines the vegetative vigor, which is fundamental for producing the mini-cuttings and consequent gains in rooting rates and root formation speed (Vilasboa et al., 2019). Under certain conditions, application of root-promoting substances in specific concentrations can generate better results in the vegetative propagation. Auxins such as indole-3-butyric acid are commonly used to induce adventitious roots in mini-cuttings (Sauer et al., 2013; Stuepp et al., 2017; Azad et al., 2018). Among its various attributes, it has the advantage of being photostable in its applications (Simon and Petrasek, 20II) and has low toxicity (Daskalakis et al., 20I8).

The genetic factor must also be considered, and studies on the rooting of species from different sources have revealed the existence of genetic variations between different genotype on the rooting potential of cuttings (Kalil Filho et al., 2007). Thus, priority should be given to using as many stock plants as possible which are representative of the population, as well as genetically diverse materials, when it is desired to obtain or plantlet with maximum genetic variability for the purposes of forest restoration. Planting related seedlings may result in future populations with a restricted genetic base, which as a result may be more vulnerable to diseases and adverse climatic conditions, threatening the long-term persistence of species (Hoffmann and Sgro, 20II).

In this sense, the objective of the present study was to establish a vegetative propagation protocol for $D$. nigra by mini-cuttings. Thus, the following hypotheses were tested: (i) the $D$. nigra species is apt to vegetative propagation using the mini-cuttings technique; (ii) there is variation between geographic origins in Viçosa and Linhares for rooting percentage and quality of roots; (iii) the use of controlled-release fertilizer improves the root growth of mini-cuttings; and (iv) higher indole-3-butyric acid (IBA) concentrations stimulate rooting and increase the vigor of the mini-cuttings rooting system.

\section{MATERIAL AND METHODS}

\section{Study area}

The experiment was conducted in the university forest nursery located in the experimental area of the Department of Forest and Wood Sciences belonging to the Federal University of Espírito Santo (DCFM-CCAUFES), Jerônimo Monteiro, ES, Brazil (latitude of $20^{\circ} 47^{\prime}$ $\mathrm{S}$; longitude of $41^{\circ} 23^{\prime} \mathrm{W}$, altitude of $120 \mathrm{~m}$ ). The region's 
climate is Cwa type (dry winter and rainy summer) according to the Köppen classification (1948), with an average annual temperature of $24.1^{\circ} \mathrm{C}$ and average annual precipitation of I, 104 mm (Lima et al., 2008).

\section{Establishment of the seed mini-garden}

The mini-stumps used in this study were originated from $D$. nigra seedlings produced by seeds from Viçosa, Minas Gerais, Brazil, and Linhares, Espírito Santo, Brazil. They were produced in $3.8 \mathrm{~L}$ polyethylene pots containing commercial substrate based on ground Pinus bark, plus 4.0 and $8.0 \mathrm{~g} \cdot \mathrm{dm}^{-3}$ of controlled release fertilizer with formulation 13-6-16 and a release time of 5 to 6 months, allocated in raised beds at $1 \mathrm{~m}$ high and under cover with transparent polyethylene plastic. Drip irrigation activated for 2 minutes was conducted 3 times a day with a flow rate of $0.1 \mathrm{~L}$ per application.

The seedlings were broken at the apical part at a height of $20 \mathrm{~cm}$ from the base when reached a total height of $30 \mathrm{~cm}$ in order to stimulate the occurrence of lateral shoots, but without ceasing the photosynthesis process. Shoots were collected at intervals of 7 days with a minimum size of $6 \mathrm{~cm}$ in length and two buds in order to let the mini-stumps conform to the cup type. Thus, the mini-clonal hedge during the experiment set-up period was formed with a total of 60 mini-stumps from each source and from each dose, with $100 \%$ survival and producing shoots in sufficient quantity to be used in the experiment (Table I).

TABLE I Characterization of the productivity of $D$. nigra ministumps as a function of controlled-release fertilizer doses.

\begin{tabular}{ccc}
\hline \multirow{2}{*}{$\begin{array}{c}\mathrm{CRF} \\
\left(\mathrm{kg} \mathrm{m}^{-3}\right)\end{array}$} & \multicolumn{2}{c}{ Productivity (mini-cuttings $/ \mathrm{m}^{2} /$ month) } \\
\cline { 2 - 3 } & \multicolumn{2}{c}{ Origins } \\
\cline { 2 - 3 } 4 & Viçosa (MG) & Linhares (ES) \\
8 & $41 \mathrm{I} .12$ & 433.8 \\
\hline
\end{tabular}

CRF - Controlled-release fertilizer.

Obtaining, preparing and staking the mini-cuttings

Apical mini-cuttings were collected in the mini-clonal hedge from the $16^{\text {th }}$ pruning in the month of August 2018. These were packed in styrofoam boxes containing water in order to maintain the vigor conditions, turgescence of the vegetative material and good physiological conditions. They were subsequently prepared with a size of $6 \mathrm{~cm}$ in length containing two pairs of leaves, and reduced to one third of their original dimension in order to minimize water losses due to transpiration and the "umbrella" effect (leaf curl) during the rooting.
The mini-cuttings bases were cut into bevels, disinfected with $0.5 \%$ sodium hypochlorite solution for 2 minutes with subsequent washing in running water, and then treated with $0.1 \%$ Captan fungicide for 2 minutes. Approximately $1.5 \mathrm{~cm}$ of the minicuttings base was immersed in powdered IBA solution in different concentrations and then staked in tubes of $55 \mathrm{~cm}^{3}$ capacity containing commercial substrate (pine bark, vermiculite, class $\mathrm{A}$ agro-industrial organic waste, wood sawdust, manure - horse beds, NPK). The IBA was dissolved in absolute ethyl alcohol and then mixed with talc, dried at room temperature and homogenized before use.

The mini-cuttings were subsequently placed in trays allocated on a suspended bed in a greenhouse with $20 \%$ reduction in light and a temperature between 25 and $30^{\circ} \mathrm{C}$, under intermittent nebulization. The nebulization was triggered when the air temperature inside the greenhouse exceeded $30^{\circ} \mathrm{C}$ or when the relative humidity was less than $80 \%$. The minicuttings were removed from the tubes after 60 days of propagation in the greenhouse, and the substrate was completely removed by washing in running water to observe the roots.

The experiment was conducted in a completely randomized design (CRD) in a $2 \times 2 \times 4$ factorial scheme (two geographic origins [Viçosa, Minas Gerais and Linhares, Espírito Santo] and two controlled release fertilizer doses $\left[4.0\right.$ and $\left.8.0 \mathrm{~g} \mathrm{dm}^{-3}\right]$ and four IBA concentrations [0; 2,000; 4,000; and 6,000 $\left.\mathrm{mg} \mathrm{Kg}^{-1}\right]$ ) with four replications, with the experimental unit consisting of 13 mini-cuttings.

\section{Mini-cuttings survival, rooting and rooting speed}

Survival (S\%) and rooting percentage (R\%) were measured. Mini-cuttings with roots greater than or equal to $0.5 \mathrm{~cm}$ were considered rooted. Rooting speed evaluations, accessed by Mean Root Emergence Time (MRET, days), were carried out daily from the date of staking until the $60^{\text {th }}$ day, where mini-cuttings with roots were observed at the lower end of the tube (Melo et al., 20II).

\section{Radicular system vigor}

Evaluations were performed regarding the largest root length (RL, cm.plant ${ }^{-1}$ ), number of roots $(N R)$, surface area $\left(\mathrm{SA}, \mathrm{mm}^{2}\right)$, root volume $\left(\mathrm{RV}, \mathrm{mm}^{3}\right)$ and root dry mass (RDM, g.plant ${ }^{-1}$ ). Roots emitted directly from the base of the mini-cuttings were considered in the counting. These were cut at the stem height, separated 
and placed to dry on absorbent paper and later digitized on an Epson scanner to determine the root volume and surface area. After being digitized, the images were submitted to the SAFIRA I.I program (Jorge et al., 2010). To determine the root dry mass (RDM, g.plant ${ }^{-1}$ ), the material was packed in paper bags and placed to dry in a forced air circulation oven at a temperature of $65^{\circ} \mathrm{C}$ until constant weight, and then weighed on an analytical scale (accurate to $0.000 \mathrm{I} \mathrm{g}$ ).

\section{Statistical analysis procedures}

The data were submitted to the assumption of normality verification test (Shapiro Wilk). Then they were subjected to analysis of variance and by the $F$ test at $5 \%$ to verify significant differences, while the means of the qualitative factors were compared by the Tukey test at the probability levels of $5 \%$ and $1 \%$. Furthermore, the means of the quantitative factor were submitted to regression analysis in order to verify the optimal IBA concentration for each variable using the first derivative of the estimators $\beta_{0}$ and $\beta_{1}$. The significance of the parameters, the t-test, the biological significance and realism of the models (linear and quadratic) as well as the coefficient of determination $\left(R^{2}\right)$ were considered for choosing the equations.

\section{RESULTS}

Mini-cuttings survival, rooting and rooting speed

There was an isolated effect for the controlledrelease fertilizer dosage factor for mean root emergence time, where the $D$. nigra mini-cuttings produced at the $8.0 \mathrm{~kg} \cdot \mathrm{m}^{-3}$ dose showed the shortest root emission time at the lower end of the tube (at 41.9 days) when compared to the $4 \mathrm{~kg} \cdot \mathrm{m}^{-3}$ dose ( 44.3 days). There was also an isolated effect for the geographical origin factor for survival (S\%) and rooting percentage ( $\mathrm{R} \%$ ) variables, with superior results for the mini-cuttings from Viçosa, MG (Table 2).

\section{Radicular system vigor}

There was an interaction $(p<0.05)$ between the origins and IBA for the largest root length (RL) and number of roots (NR) traits, in which the mini-cuttings from TABLE 2 Survival $(S)$ and rooting $(R)$ of $D$. nigra mini-cuttings, depending on the origin at 60 days.

\begin{tabular}{ccc}
\hline Origin & Survival $(\%)$ & Rooting $(\%)$ \\
\hline Viçosa-MG & $81.70 \mathrm{a}$ & $80.52 \mathrm{a}$ \\
Linhares-ES & $69.47 \mathrm{~b}$ & $67.06 \mathrm{~b}$ \\
\hline
\end{tabular}

Means followed by equal letters in the column do not differ statistically from each other by the Tukey test at the $5 \%$ probability level.
Linhares showed better performance, with a maximum value of $11.2 \mathrm{~cm} \cdot$ plant $^{-1}$ and 9.9 roots, respectively, reached with the $6,000 \mathrm{mg} \cdot \mathrm{Kg}^{-1}$ concentration, with an increasing linear growth trend (Figure IA, IB). There was no significant effect of the tested regression models for the mini-cuttings from Viçosa (I I.04 cm.plant ${ }^{-1}$ and 6.94 roots, respectively).
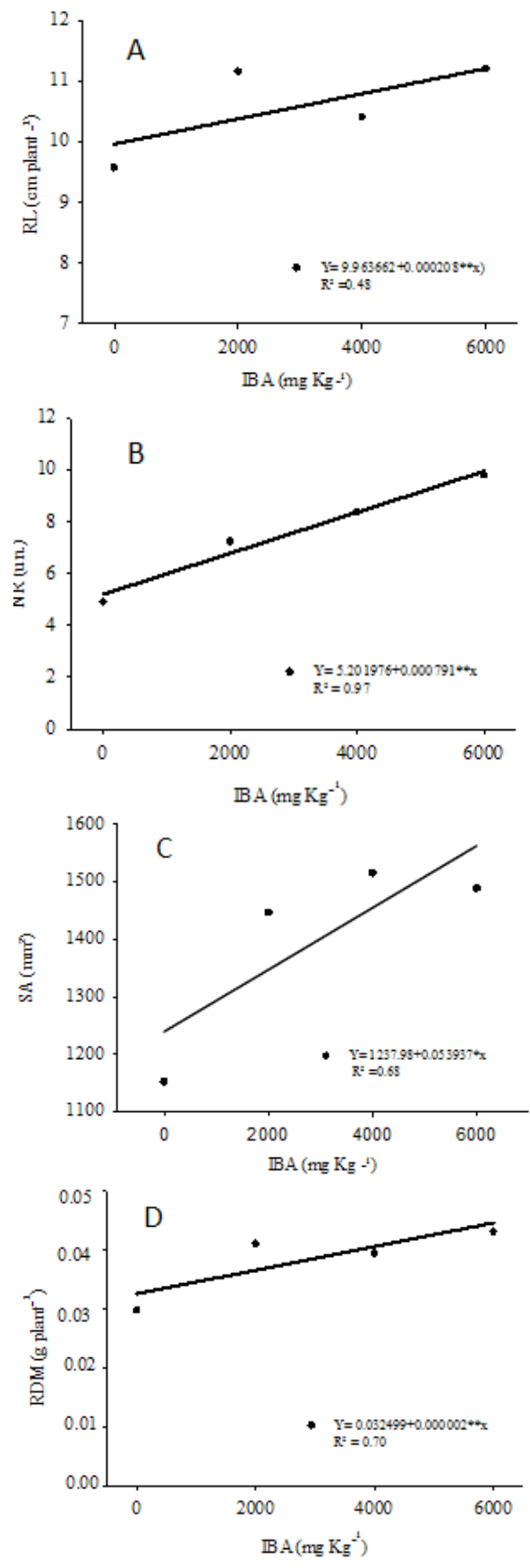

FIGURE I (A) length of the largest root; (B) number of roots per mini-cutting; (C) surface area; (D) root dry mass of $D$. nigra mini-cuttings subjected to different concentrations of indole-3-butyric acid, 60 days after staking. ${ }^{*}$ and *** significant at $5 \%$ and $1 \%$ probability, respectively. 
The individual effect for the IBA factor was observed for SA and RDM, where the maximum increment value of I,487.97 $\mathrm{mm}^{2}$ and $0.0444 \mathrm{~g}$.plant ${ }^{-1}$, respectively, was observed at the dose of $6,000 \mathrm{mg} \cdot \mathrm{Kg}^{-1}$, with a tendency to increasing linear growth (Figure IC, ID). There was also a significant effect of the interaction between the CRF dosage factors and origins for the RDM variable of minicuttings (Table 3), where the $8 \mathrm{~kg} \cdot \mathrm{m}^{-3} \mathrm{CRF}$ combination for the Linhares origin mini-cuttings increased more.

TABLE 3 Interaction between the controlled release fertilizer (CRF) doses and geographical origins for the root dry mass (RDM) of $D$. nigra mini-cuttings.

\begin{tabular}{|c|c|c|}
\hline \multirow{3}{*}{$\begin{array}{c}\text { CRF } \\
\left(\mathrm{kg} \cdot \mathrm{m}^{-3}\right)\end{array}$} & \multicolumn{2}{|c|}{ MSR $\left(g \cdot\right.$ plant $\left.^{-1}\right)$} \\
\hline & \multicolumn{2}{|c|}{ Origins } \\
\hline & Viçosa (MG) & Linhares (ES) \\
\hline 4 & $0.0380 \mathrm{Aa}$ & $0.0342 \mathrm{Ba}$ \\
\hline 8 & $0.0355 \mathrm{Ab}$ & $0.045 \mathrm{IAa}$ \\
\hline
\end{tabular}

Means followed by lowercase and uppercase letters equal in the row and column, respectively, do not statistically differ from each other by the Tukey test at $5 \%$ probability level.

\section{DISCUSSION}

Mini-cuttings survival, rooting and rooting speed

Considering that commercial clonal forest nurseries generally prefer to propagate species with at least $70 \%$ rooting (Hunt et al., 20I I; Rigby and Trueman, 2015), the first hypothesis of the present study can be considered partially confirmed. It is possible to propagate $D$. nigra species by mini-cuttings from juvenile shoots from seedlings with satisfactory survival and rooting index rates, which are crucial variables and considered determinants for the success of the mini-cuttings technique.

The $\mathrm{S}(\%)$ and the $\mathrm{R}(\%)$ of the $D$. nigra minicuttings were similar to other forest species, such as Erythrina falcata (Cunha et al., 2008) and Peltophorum dubium (Mantovanii et al., 2017), all presenting averages above $70 \%$ for the survival and rooting of mini-cuttings. In contrast, averages of 85.3 and 73.18 were obtained for S (\%) and 45.3 and 16.67 for R (\%), for Anadenanthera macrocarpa (Dias et al., 2015) and Plathymenia reticulata (Pessanha et al., 20I8), respectively, showing that species of the Fabaceae family do not follow a rooting pattern.

However, there were significant differences in $\mathrm{S}(\%)$ and $\mathrm{R}(\%)$ between the tested origins, validating the second hypothesis. These results infer that these variations come from genetic control or even from the differences between the endogenous balances of the plant related to physiological and morphological factors (Mankessi et al., 2009). Even though they are of the same species, the seeds in each mother plant development location are subject to variations in physiological quality due to edaphoclimatic differences and other variants which end up highlighting certain aspects of their genetic composition, which would not manifest in another location (Lima et al., 2018).

Plants can present a set of responses for cuttings rooting, which can vary in a complex way between genotypes (Schwaegerle, 2005; Xavier et al., 20I3). Dias et al. (20I2) found a heterogeneous response among the Anadenanthera macrocarpa progenies regarding the rooting percentage of apical mini-cuttings, with values between $66.7 \%$ and $85.5 \%$. Granja et al. (20I8) and Cati et al. (2014) found that the aptitude for in vitro rooting and the survival of seedlings ex vitro were also dependent on the genotype. The authors reiterate that the genetic factor within the species is yet another parameter to be considered for maximizing rooting potential.

The hypothesis that mineral nutrition of the stock plant modulates the root growth of $D$. nigra mini-cuttings was also confirmed. The highest tested CRF dose promoted an accelerated root growth observed in the means of the MRET variable, as well as an increase in the mini-cutting productivity per $\mathrm{m}^{2}$ (Table I). The ability of plant tissues to form adventitious roots and the nutrition of the parent plant are closely correlated and decisive events in forming quality clonal plants.

The nutritional condition of the collected propagule determines the amount of metabolic compounds, such as carbohydrates and auxins, which are essential to the rhizogenesis initiation and speed (Xavier et al., 2013; Pereira and Peres, 2016; Almeida et al., 2017). According to Dias et al. (20I2), the more nourished the plant, the greater the number of cells produced by the meristems and the longer the growth axis will be, thus reaching the lower end of the tube in a short time. MRET is a nondestructive variable used in most forest nurseries as an important indication of rooting, as it enables a practical indication of when to transfer plants to the later stages of the production process (Borges et al., 20II).

\section{Radicular system vigor}

Although indole-3-butyric acid was not a condition for $\mathrm{R}(\%)$ regarding the vigor of the formed root system, the exogenous application of this plant regulator promoted significant gains for RL, NR, SA and RDM, which partially proves the fourth hypothesis. This result was also observed by Oliveira et al. (2016) in minicuttings of Handroanthus heptaphyllus, and by Mantovani et al. (2017) for Peltophorum dubium. 
The emission of a larger number of roots with greater length and contact area by the root system in $D$. nigra plants is fundamental for increasing the soil volume to be explored, thereby favoring acquisition of water and nutrients, which in turn constitute factors which may be useful for increasing survival rates and the initial growth of this species in the field. According to Gibson et al. (2019), seedlings with a vigorous root system can establish themselves more quickly in adverse conditions, recover and increase microbiological activity in the soil, in addition to contributing to the increase of biomass, aggregation and soil structure.

It was also observed that the geographic origin of the propagule influenced the root system quality, as the mini-cuttings from Linhares showed superior performance for RL and NR. These contrasting differences between the origins can be explained by the genetic variability, or also by the physiological conditions of the parent plants at the time of seed collection. The phenotypic variations between plants propagated via asexual result from the interaction between the genotypic effects, environmental effects and the "genotype $x$ environment" interaction (Xavier et al., 2013). Therefore, there is a response based on genetic variability and adaptation to edaphoclimatic conditions, which are probably responsible for different internal compounds and concentrations between plant genotypes (Lima et al., 2018).

It is also noteworthy that the Linhares origin was more responsive to CRF addition in relation to Viçosa in terms of root dry matter production. According to Ferreira and Araújo (198I), the importance of working with seeds from different locations under a geographic and climatic perspective enables verifying the genetic differences within the species, and the phenotypic differences determined by environmental variations. In knowing the natural variability, you can select individuals or materials which have superior characteristics, and thus provide information on potential parents to be used in breeding and genetic conservation programs (Borém and Miranda, 2009). According to Botezelli et al. (2000), studying different origins makes it possible to capture various expressions of the genotype made possible by the different environmental conditions of the occurrence location.

Therefore, given the suitability of $D$. nigra minicuttings technique as a method of vegetative propagation using juvenile propagules, the plant production technique is recommended as an alternative to propagation via seeds. Furthermore, we suggest that studies should be carried out to analyze the residual effect of using IBA in all stages of the plant production cycle and in its field establishment in order to assess the viability of using this regulator in propagating $D$. nigra via mini-cuttings technique. It is important to highlight that the use of IBA requires a cost to the nursery, less optimization in the staking activity and a storage location, therefore implementing this chemical in practical terms is at the producer's discretion for propagating D. nigra via mini-cuttings.

\section{CONCLUSIONS}

Mini-cuttings technique of juvenile shoots from seedlings is technically feasible for propagating $D$. nigra. The geographical origins present a different set of responses and behavior in the survival, rooting and vigor of the minicuttings. The mother plant's nutrition influences the minicuttings root growth. The different indole-3-butyric acid concentrations do not have an effect on the mini-cuttings rooting percentage, but they do promote greater vigor of the root system. However, further research is suggested to define the feasibility of using this regulator in vegetative propagation of $D$. nigra plants.

\section{ACKNOWLEDGEMENTS}

This study was financid in part by the Coordenação de Aperfeiçoamento de Pessoal de Nível Superior - Brazil (CAPES) - Código de Financiamento 00I; by the Fundação de Amparo à Pesquisa e Inovação do Espírito Santo (FAPES), by the Secretaria de Estado de Agricultura, Abastecimento, Aquicultura e Pesca do Estado do Espírito Santo (SEAG), by the Rosal Energia, by the Programa de Pós-Graduação em Ciências Florestais da Universidade Federal do Espírito Santo.

\section{REFERENCES}

ABIYU, A.; DEJENE, T.; ESHETE, A.; SISAY, K. Vegetative propagation of Boswellia papyrifera: time of collection and propagule size affect survival and establishment. Journal of Arid Environments, v. 133, p. 122-124, 2016.

ALMEIDA, M. R.; AUMOND, M.; DA COSTA, C. T.; SCHWAMBACH, J.; RUEDELL, C. M.; CORREA, L. R.; FETT-NETO, A. G. Environmental control of adventitious rooting in Eucalyptus and Populus cuttings. Trees, v. 31 , n. 5, p. I377-I390, 2017.

AZAD, M.; MATIN, M. Effect of indole-3-butyric acid on clonal propagation of Swietenia macrophylla through branch cutting. Journal of Botany, v. 2015, 2015.

AZAD, M. S.; ALAM, M. J.; MOLLICK, A. S.; MATIN, M. A. Responses of IBA on rooting, biomass production and survival of branch cuttings of Santalum album L., a wild threatened tropical medicinal tree species. Journal of Science, Technology and Environment Informatics, v. 2, n. 3, p. 195-206, 2016 
AZAD, M. S.; ALAM, M. J.; MOLLICK, A. S.; KHAN, M. N. I. Rooting of cuttings of the wild Indian almond tree (Sterculia foetida) enhanced by the application of indole-3-butyric acid (IBA) under leafy and non-leafy conditions. Rhizosphere, v. 5, p. $8-15,2018$.

BAUL, T. K.; MEZBAHUDDIN, M.; HOSSAIN, M. M.; MOHIUDDIN, M. Vegetative propagation of Holarrhena pubescens, a wild tropical medicinal plant: effect of indole3-butyric acid (IBA) on stem cuttings. Forestry Studies in China, v. 12, n. 4, p. 228-235, 2010.

BORÉM, A.; MIRANDA, G. V. Melhoramento de plantas. Viçosa, UFV, 2009. 529p.

BORGES, S. R.; XAVIER, A.; OLIVEIRA, L. S.; MELO, L. A.; ROSADO, A. M. Enraizamento de miniestacas de clones híbridos de Eucalyptus globulus. Revista Árvore, v. 35, n. 3, p. 425-434, 201 I.

BOTEZELLI, L.; DAVIDE, A. C.; MALAVASI, M. M. Características dos frutos e sementes de quatro procedências de Dipteryx alata Vogel (Baru). Cerne, v. 6, n. I, p. 9-18, 2000.

BRASIL. Ministério do meio ambiente, 20I4. Instrução Normativa n. 443, de 17 de setembro de 20/4. Lista Oficial das Espécies da Flora Brasileira Ameaçadas de Extinção. Diário Oficial da República Federativa do Brasil, Brasília, DF. http://cncflora.jbrj.gov.br/portal/static/pdf/portaria mma_443_20l4.pdf (acesso em 03 de novembro de 2019).

CARVALHO, P. E. R. Espécies arbóreas brasileira. Colombo, Embrapa, 2003. 1039p.

CATI, M.; GENNARI, F.; MARINO, G. Effect of culture jar seal on in vitro rooting and subsequent acclimatization of three Italian apricot varieties. Scientia Horticulturae, v. I68, p. I20-|23, $20 \mid 4$.

CORREIA, A. C. G.; XAVIER, A.; DIAS, P. C.; TITON, M.; SANTANA, R. C. Redução foliar em miniestacas e microestacas de clones híbridos de Eucalyptus globulus. Revista Árvore, v. 39, n. 2, p. 295-304, 2015.

CUNHA, A. C.; WENDLING, I.; SOUZA JÚNIOR, L. Miniestaquia em sistema de hidroponia e em tubetes de corticeira-do-mato. Ciência Florestal, v. 18, n. I, p. 8592, 2008.

DASKALAKIS, I.; BINIARI, K.; BOUZA, D.; STAVRAKAKI, M. The effect that indolebutyric acid (IBA) and position of cane segment have on the rooting of cuttings from grapevine rootstocks and from Cabernet franc (Vitis vinifera L.) under conditions of a hydroponic culture system. Scientia Horticulturae, v. 227, p. 79-84, 2018.

DIAS, P. C.; XAVIER, A.; OLIVEIRA, L. S. D.; PAIVA, H. N. D.; CORREIA, A. C. G. Propagação vegetativa de progênies de meios-irmãos de angico-vermelho (Anadenanthera macrocarpa (Benth) Brenan) por miniestaquia. Revista Árvore, v. 36, n. 3, p. 389-399, 2012.
DIAS, P. C.; XAVIER, A.; DE OLIVEIRA, L. S.; CORREIA, A. C. G.; BARBOSA, G. A. Tipo de miniestaca e de substrato na propagação vegetativa de Angico-vermelho (Anadenanthera macrocarpa (Benth.) Brenan). Ciência Florestal, v. 25, n. 4, p. 909-919, 2015

FERNANDES, S. J. O.; SANTANA, R. C.; SILVA, E. B.; SOUZA, C. M. P.; SILVA, C. T. Período de enraizamento de miniestacas de eucalipto provenientes de diferentes lâminas de irrigação em minijardim. Ciência Florestal, v. 28 , n. 2, p. 59I-600, 2018

FERREIRA, M.; ARAÚJO, A. J. Procedimentos e recomendações para teste de procedência. Curitiba: EMBRAPA, I98I, 28 p.

FREITAS, A. F. D.; PAIVA, H. N. D.; XAVIER, A; NEVES, J. C. L. Productivity of ministumps and rooting of minicuttings of hybrids of Eucalyptus globulus labill in response to nitrogen. Ciência Florestal, v. 27, n. I, p. 193-202, 2017.

GATTI, K. C.; GONÇALVES, R. C.; XAVIER, A.; PAIVA, H. Propagação vegetativa de Jequitibá (Cariniana estrellensis (Raddi) por miniestaquia. Temas Agrários, v. 16, n. 2, p. 54-63, 2011.

GIBSON, E. L.; GONÇALVES, E. D. O.; SANTOS, A. R. D.; ARAÚJO, E. F.; CALDEIRA, M. V. W. Controlled-Release Fertilizer on Growth of Melanoxylon brauna Schott Seedlings. Floresta e Ambiente, v. 26, n. SPEI, 2019.

GRANJA, M. M.; MOTOIKE, S. Y.; ANDRADE, A. P. S.; CORREA, T. R.; PICOLI, E. A.; KUKI, K. N. Explant origin and culture media factors drive the somatic embryogenesis response in Acrocomia aculeata (Jacq.) Lodd. ex Mart., an emerging oil crop in the tropics. Industrial Crops and Products, v. II7, p. I-12, 2018.

HARTMANN, H. T.; KESTER, D. E.; DAVIES JR., F. T.; GENEVE, R. L. Plant propagation: principles and practices. New Jersey, Englewood Clipps, 201 I. 900 p.

HOFFMANN, A. A.; SGRÒ, C. M. Climate change and evolutionary adaptation. Nature, v. 470, n. 7335, p. 479,2011

HUNT, M. A.; TRUEMAN, S. J.; RASMUSSEN, A. Indole-3butyric acid accelerates adventitious root formation and impedes shoot growth of Pinus elliottii var. elliottii $\times P$. caribaea var. hondurensis cuttings. New Forests, v. 4I, n. 3, p. 349-360, $201 \mathrm{I}$

JANNAT, M.; HOSSAIN, M. K.; ALAM, M. S.; HOSSAIN, M. A.; KAMRUZZAMAN, M. Vegetative propagation of Tali (Palaquium polyanthum Engl.) for commercial harvest and landscape conservation. Rhizosphere, v. 3, n. I, p. 9-12, 2017.

JORGE, L. A. C. et al. SAFIRA - Software para a análise de fibras e raízes. Versão I.I. São Carlos: Embrapa Instrumentação Agropecuária, 2010. 
KALIL FILHO, A. N.; HOFFMANN, H. A.; WENDLING, I. Propagação vegetativa de liquidambar por enxertia. Colombo: Embrapa Florestas, 2007. 7 p. (Circular técnica, I37).

KOPPEN, W. Climatologia: com um estudio de los climas de la tierra. Buenos Aires, Fondo de Cultura Economica, 1948, $495 \mathrm{p}$

LIMA, J. S. S.; SILVA, S. A.; OLIVEIRA, R. B.; CECÍLIO, R. A.; XAVIER, A. C. Variabilidade temporal da precipitação mensal em Alegre - ES. Revista Ciência Agronômica, v. 39, n. 02, p. 327 - 332, 2008.

LIMA, H. C. de 20I5. Dalbergia in Lista de Espécies da Flora do Brasil. Jardim Botânico do Rio de Janeiro. Disponível em: <http://floradobrasil.jbrj.gov.br/jabot/ floradobrasil/FB229I5>. Acesso em: 10 de set de 2019.

LIMA, C. C.; OHASHI, S. T.; SILVEIRA, A. S. Efeito de diferentes concentrações de AIB e procedências geográficas no enraizamento de estacas de paricá. Ciência Florestal, v. 28 , n. 3, p. $1282-1292,2018$.

LORENZI, H., 2009. Árvores brasileiras: manual de identificação e cultivo de plantas arbóreas nativas do Brasil. Nova Odessa, Plantarum. 384p.

MANKESSI, F; SAYA, A.; BAPTISTE, C.; NOURISSIER, S.; MONTEUUIS, O. In vitro rooting of genetically related Eucalyptus urophylla $\times$ Eucalyptus grandis clones in relation to the time spent in culture. Trees, v. 23, n. 5, p. 931-940, 2009.

MANTOVANI, N.; ROVEDA, M.; TRES, L.; FORTES, F. D. O.; GRANDO, M. F. Cultivo de canafístula (Peltophorum dubium) em minijardim clonal e propagação por miniestacas. Ciência Florestal, v. 27, n. I, p. 225-236, 2017.

MELO, L. A.; XAVIER, A.; DE PAIVA, H. N.; BORGES, S. R. Otimização do tempo necessário para o enraizamento de miniestacas de clones híbridos de Eucalyptus grandis. Revista Árvore, v. 35, n. 4, p. 759-767, 201 I.

OLIVEIRA, T. P. F.; BARROSO, D. G.; LAMÔNICA, K. R.; CARVALHO, G.C.M.W.Aplicação de AlB e tipo de miniestacas na produção de mudas de Handroanthus heptaphyllus Mattos. Ciência Florestal, v. 26, n. I, p. 3|3-320, 2016.
PEREIRA, F. B.; PERES, F. S. B. Nutrição e enraizamento adventício de plantas lenhosas. Pesquisa Florestal Brasileira, v. 36, n. 87, p. 319-326, 2016.

PESSANHA, S. E. G. L.; BARROSO, D. G.; BARROS, T. C.; DE OLIVEIRA, T. P. D. F.; DE CARVALHO, G. C. M. W.; DA CUNHA, M. Limitações na produção de vinhático (Plathymenia reticulata Benth) por miniestaquia. Ciência Florestal, v. 28, n. 4, p. I688-1703, 2018.

RIGBY, E. M.; TRUEMAN, S. J. Umbrella Fern: A New Ornamental Crop. Acta Horticulturae, v. I097, p. 221-226, 2015.

SAUER, M.; ROBERT, S.; KLEINE-VEHN, J. Auxin: simply complicated. Journal of Experimental Botany, v. 64, n. 9, p. 2565-2577, 2013.

SIMON, S.; PETRÁSEK, J. Why plants need more than one type of auxin. Plant Science, Limerick, v. I80, p. 454-460, 20 I I.

SCHWAEGERLE, K. E. Quantitative genetic analysis of plant growth: biases arising from vegetative propagation. Evolution, v. 59, n. 6, p. I259-I 267, 2005.

STUEPP, C. A.; WENDLING, I.; TRUEMAN, S. J.; KOEHLER, H. S.; ZUFFELLATO-RIBAS, K. C. The use of auxin quantification for understanding clonal tree propagation. Forests, v. 8, n. I, p. I-I5, 2017.

VILASBOA, J.; DA COSTA, C. T.; FETT-NETO, A. G. Rooting of eucalypt cuttings as a problem-solving oriented model in plant biology. Progress in Biophysics and Molecular Biology, v. 146, p. 85-97, 2018.

XAVIER, A.; WENDLING, I.; SILVA, R. L. Silvicultura clonal: Princípios e Técnicas. Viçosa, UFV, 20I3, 280 p.

WENDLING, I.; BRONDANI, G. E.; BIASSIO, A.; DUTRA, L. F. Vegetative propagation of adult llex paraguariensis trees through epicormic shoots. Acta Scientiarum. Agronomy, v. 35, n. I, p. II7-125, 2013.

WENDLING, I; TRUEMAN, S. J; XAVIER, A. Maturation and related aspects in clonal forestry - part II: reinvigoration, rejuvenation and juvenility maintenance. New Forests, v. 45, n. 4, p. 473-486, 20 I4. 